\title{
Identification and Validation of Different Types of Fruit of Haritaki (Terminalia chebula Retz.) in North-Western Ghats of North Karnataka with Special Reference to HPTLC
}

\author{
Ajanal Manjunath ${ }^{1, *}$, Kotturshetty B Iranna ${ }^{2}$, Ullegaddi Vinod ${ }^{1}$ \\ 'Department of Dravya Guna, Rajiv Gandhi Education Society's, Ayurvedic Medical College Hospital and PG Research centre Ron, Gadag, Karnataka, INDIA. \\ 2Department of Panchakarma, Rajiv Gandhi Education Society's, Ayurvedic Medical College Hospital and PG Research Centre Ron, Gadag, Karnataka, INDIA.
}

\begin{abstract}
Background: The fruit of Myrobalan (Terminalia chebula Retz.) is considered as Amruta (Nectar) and 'King of Medicines' in Ayurveda, it known to be have 7-varieties with differences in botanical and pharmacological characters. Actual identification of these variety and it's botanical correlation was not done. Thus, present study was done to identify these varieties in North-Western Ghats of North Karnataka and correlate its chemo-profile by HPTLC method. Methods: A prospective survey study was conducted in 10 localities of north-western Ghats of north Karnataka along with GPS system and identified and collected. The fruit was analyzed on Shape, Size, Dimension, Weight per fruit, color, mesocarp contents, seed character and size in relation with Ayurvedic classification and respective microscopic histology and Powder characters, Physico and phyto-chemical, HPTLC. Results: The study identified 5 varieties as Vijaya (Termenalia chebula Ver. 2 (typica)), Rohini (Termenalia chebula Ver. 3 (citrina)), Pootana (Termenalia chebula Ver. Tomentella), Amirtha (Termenalia chebula Ver. Gangitica) and Abhaya (Termenalia chebula Ver. Parviflora, Thewaites Enum). Further, each variety has difference on its botanical, organoleptic, physicochemical analy-
\end{abstract}

sis. The \% of Chebulinic acid was maximum of $6.4 \%$ in abhaya compare to least in Amritha of $3.8 \%$ and Gallic acid is more in Rohini (4.3\%) compare to least in Pootani $(2.1 \%$ ) and rest of other chemicals were identified in traces. Conclusion: The study potentially demonstrated the availability of varieties of Myrobalan, there was enormous differences on its phytochemicals by HPTLC.

Key words: Haritaki, Myrobalan, HPTLC, Chebulinic acid, Gallic acid, Ayurveda.

Correspondence

Dr. Ajanal Manjunath,

Department of Dravyaguna, Associate Professor, RGES's Ayurvedic Medical College, Hospital and PG Research Center, Ron- 582209, Gadag, Karnataka, INDIA.

Phone: +91- 09036616510

Email: manju.ajanal@gmail.com

DOI: 10.5530/jyp.2019.11.52

\section{INTRODUCTION}

Myrobalan (Haritaki) or Terminalia chebula Retz. is a member of the Combretaceae family, is used widely in Asian countries as a traditional folk medicine or Ayurveda. Moreover, this plant is considered as Amruta (Nectar) and 'King of Medicines' in Ayurveda because of it's wide range of therapeutic benefits from mild purgative to immune modulation. ${ }^{1} \mathrm{Be}$ cause of its huge beneficial effects this plant has gain special attention in Ayurveda by providing details about its botanical and pharmacological characters.

In Ayurveda, The Bhavaprakash lexicon has described T. chebula varieties along with sources, identity features and therapeutic uses as presented in Table 1. ${ }^{2}$ Likewise, Hooker's flora of British India has identified this plant in to 6-different varieties as ${ }^{3}$ Terminalia chebula Retz. (Variety chebula proper), Terminalia chebula (var. typica), Terminalia chebula (Var. citrina), Terminalia chebula (Var. tomentella Kurz.), Terminalia chebula (Var. gangetica Roxb) and Terminalia chebula (Var. parviflora Thwaitos Enum.). Similarly these various varieties may clubbed identified as 2 varieties by Brandis as Ordinary variety and Tomentose form. ${ }^{4}$ In spite of vast therapeutic use of T. chebula, the identification and correlation with botanical sources and variation in chemo-profile is yet to be known.

Terminalia chebula Retz. is a medium sized deciduous tree grows up to $25 \mathrm{~m}$ tall with broadly elliptic leaves clustered at the ends of branches. The leaves are alternate or opposite, thin-coriaceous, ovate or ellipticobovate. Flowers in axillary long spikes, simple or sometime branched, about $4 \mathrm{~mm}$ across, yellowish-white and unpleasantly scented. The fruits of this plant are spherical to ovoid, 1.2 to $3.5 \mathrm{~cm}$ in diameter and tapering towards both the ends. The dry fruits are grayish brown in colour, pubescent and slightly ridged. ${ }^{5-7}$ These fruits of T. chebula are rich in tannins (about 32\%-34\%), ${ }^{8,9}$ of which gallic acid, chebulagic acid, ellagic acid, chebulinic acid are hydrolysable tannins, phenolics and anthraquinones. ${ }^{10}$ polyphenols are present in traces. ${ }^{11-13}$ Fatty acids include palmitic acid, linoleic acid and oleic acid. ${ }^{14}$ Triterpenoid glycosides such as chebulosides I and II, arjunin, arjunglucoside, $2 \alpha$-hydroxyursolic acid and $2 \alpha$-hydroxymicromiric acid also have been reported. ${ }^{15}$

This plant is found in the Sub Himalayan tracks from Ravi eastwards to West Bengal and Assam, ascending upto the altitude of $1500 \mathrm{~m}$ in the Himalayas. This tree is wild in forests of Northern India, central provinces and Bengal, common in Madras, Mysore and in the southern part of the rainy and moderate temperate region of Bombay presidency. ${ }^{16}$ Western ghat is one of the biological hot spot situated in India it has wide range of plant and animal Kingdome. One such popular plant Kingdome available is T. chebula. The primary report published by Regional Medical Research Centre (RMRC a unit of ICMR) suggested that different shapes of fruits of T. chebula are available in Western Ghats of North Karnataka thus present area was selected. Phytochemical evaluation is one of the tool for the quality assessment, which includes preliminary phytochemical screening, chemoprofiling and marker compound analysis using modern analytical techniques. In the last two decades High Performance Thin Layer Chromatography (HPTLC) method has emerged as an im-

This is an open access article distributed under the terms of the Creative Commons Attribution-NonCommercial-ShareAlike 4.0 License, which allows others to remix, tweak, and build upon the work non-commercially, as long as the author is credited and the new creations are licensed under the identical terms. 
portant tool for the qualitative and quantitative phytochemical analysis of herbal drugs and formulations. Fruits of T. chebula have different therapeutic actions with respect to different types. Hence, present study was thus planned with the objective of identify the different available types of fruit of Haritaki (Terminalia chebula Retz.) in North-Western Ghats of North Karnataka and to evaluate the chemo-profile variation of identified varieties of fruit of Haritaki (Terminalia chebula Retz.) by HPTLC.

\section{MATERIALS AND METHODS}

A prospective survey study was conducted across north-western Ghats of north Karnataka to identify and collect the fruits and Terminalia chebula Retz. Rutin, quercetin, chebulinic acid and gallic acid were procured from Natural remedies, Bangaluru. Toluene, acetone, ethyl acetate, dichloromethane, formic acid, glacial acetic acid and methanol etc. are analytical grade purchased from E-Merck and silica gel F254 precoated TLC aluminium plates (E-Merck) were used.

\section{Survey Localities and Effort}

During the study period investigator has visited 10 localities across north-western Ghats of North Karnataka (From $14^{\circ} \mathrm{C} 46^{\prime} \mathrm{N}-75^{\circ} \mathrm{C} 12^{\prime}$ $\mathrm{E}$ to $15^{\circ} \mathrm{C} 52^{\prime} \mathrm{N}-74^{\circ} \mathrm{C} 34^{\prime} \mathrm{E}$ ): which includes 7 reserved forests as Jamboti and Kanakumbi, Dandeli, Ganesh Gudi, Gungargatti, Kappatgudda and Tadasa and 3 plantations landscape are Karnataka University Herbal Garden Dharwad, Bhimgad Wildlife Sanctuary Jamboti, Belgaum and Bakala herbal Garden Sirsi. Karawar of North Karnataka with GPS system. Each area was primarily visited to locate plant of Terminalia chebula Retz. and noted in GPS system. Thus, identified plants of area were further visited three times (Summer, Rainy and winter) to note plant morphological and botanical identification in details.

\section{Plant Identification}

A team including Principal Investigator (PI), Co-investigator (Co-PI) and Field collector were locate tree of TC on their first field visit then plant identification was by preparing voucher specimen along with herbarium in coordination with Scientist of Regional Medical Research Centre (RMRC) a unit of ICMR Belgaum and preserved at Dept of Dravyaguna RGES AMC Ron. In successive three field visit, identified plants were studied on its morphology and fruit etc.

\section{Fruit collection}

Thus, identified plants from 10 localities fruits were collected after full maturity and analyze according specified assessment criteria. All the collected varieties are carefully photographed and preserved.

\section{Assessment of fruit}

Shape, Size, Dimension, Weight per fruit, color, mesocarp contents, seed character and seed size etc. were assessed and compared with Table 1 of Ayurvedic classification of fruit.

Further each classified fruit was further analyzed on its microscopic histology and Powder characters, Physico-chemical and Phytochemical study. All these examinations were done at Research Analytical Lab (Government of Karnataka Supported Laboratory) of Rajiv Gandhi education Society's Ayurvedic Medical College, Hospital and PG Research Centre, Ron. India.

\section{HPTLC Study}

Study was done at GMP certified Anchrome Laboratory Mumbai. ${ }^{17}$ Dried fruits were made into coarse powder and extracted with ethyl alcohol and water by soxhlet apparatus. The extract was filtered using Whatman filter paper and then concentrated in vacuum and dried.

\section{Preparation of Standard and Sample Solutions}

Gallic acid, rutin, chebulin acid and quercetin $10 \mathrm{mg}$ were accurately weighed into a $10 \mathrm{~mL}$ volumetric flask, dissolved in $5 \mathrm{~mL}$ methanol and the solution was made up to $10 \mathrm{~mL}$ with the same solvent $(1 \mathrm{mg} / \mathrm{mL}) .5$ varieties of $T$. chebula fruit extract was accurately weighed (100 mg) into a $10 \mathrm{~mL}$ volumetric flask, dissolved in methanol and then solution was filtered through Whatman filter paper No. 42 and the filtrate was made up to the mark with methanol.

\section{Development of HPTLC Technique}

Alcoholic and water extracts of 5-varieties of T. chebula and standard methanolic Rutin, Querceitn, Chebulinic acid and gallic acid were spotted on a specified TLC sheets $(20 \times 10 \mathrm{~cm}, 0.2 \mathrm{~mm}$ thickness $)$ as $8 \mathrm{~mm}$ wide band width by using automatic TLC applicator CAMAG TLC Sampler 4 (ATS 4),10mm from the bottom. The Mobile phase used was Ethyl formate: Toluene: Formic acid: Water (30:1.5:4:3 v/v/v/v). The plates were kept for saturation in twin trough chamber for 20min. After development the plates were dried in air and scanned at 190 - $450 \mathrm{~nm}$ for Rutin, Querceitn, Chebulinic acid and gallic acid by using CAMAG Scanner 4 operated by wincats software 4.03 version. The plates were photographed after derivatization with Natural products at white light and $366 \mathrm{~nm}$ by using CAMAG TLC Visualizer 2.

\section{RESULTS}

The study has reported 5 varieties Terminalia chebula and preserved. The collected samples of voucher specimen and herbarium were prepared and discussed with Scientist of RMRC Belgaum and preserved at Dept. of Dravyaguna RGES Ayurvedic Medical College and Hospital Ron with specimen no RGES/CRC/AUT/20A/16. These plants are identified as Termenalia chebula Ver. 2 (typica), Termenalia chebula Ver. 3 (citrina), Termenalia chebula Ver. Tomentella, Termenalia chebula Ver. Gangitica and Termenalia chebula Ver. Parviflora, Thewaites Enum. Further, each

Table 1: Ayurvedic Varieties of Terminalia chebula Retz. with properties. $^{7}$

\begin{tabular}{|c|c|c|c|c|}
\hline SI. No & Variety & $\begin{array}{c}\text { Textual } \\
\text { Characters }\end{array}$ & $\begin{array}{l}\text { Presumed } \\
\text { Characters }\end{array}$ & Uses \\
\hline 1. & Vijaya & $\begin{array}{l}\text { Having Alabu } \\
\text { (Fruit of Lage- } \\
\text { naria vulgaris } \\
\text { Ser.) shape }\end{array}$ & $\begin{array}{l}\text { Elongated shape } \\
\text { without ridges and } \\
<8 \mathrm{gm}\end{array}$ & $\begin{array}{l}\text { Used in all } \\
\text { diseases }\end{array}$ \\
\hline 2. & Rohini & Round in shape & $\begin{array}{l}\text { Circular, without } \\
\text { ridges yellow color }\end{array}$ & $\begin{array}{l}\text { Used in } \\
\text { vrana (ulcer) }\end{array}$ \\
\hline 3. & Pootana & $\begin{array}{l}\text { Size is small, } \\
\text { with stony } \\
\text { mesocarp and } \\
\text { big seed }\end{array}$ & $\begin{array}{l}\text { Very small size with } \\
<4 \text { gm weight with } \\
\text { stony mesocarp and } \\
\text { big seed }\end{array}$ & $\begin{array}{l}\text { External } \\
\text { purpose }\end{array}$ \\
\hline 4. & Amirtha & $\begin{array}{l}\text { Mesocarp } \\
\text { is more and } \\
\text { fleshy }\end{array}$ & $\begin{array}{c}\text { Mesocarp is more } \\
\text { and fleshy with small } \\
\text { seed }<7 \mathrm{gm}\end{array}$ & $\begin{array}{l}\text { Used for } \\
\text { shodhana } \\
\text { karma (Puri- } \\
\text { fication) }\end{array}$ \\
\hline 5. & Abhya & $\begin{array}{l}\text { Fruit having } \\
\text { five ridges }\end{array}$ & $\begin{array}{l}\text { Fruit having five } \\
\text { ridges and weighs } \\
7-9 \mathrm{gm}\end{array}$ & $\begin{array}{l}\text { Used for eye } \\
\text { diseases }\end{array}$ \\
\hline 6. & Jivanti & $\begin{array}{l}\text { Fruit is golden } \\
\text { yellow }\end{array}$ & $\begin{array}{l}\text { Fruit is golden yel- } \\
\text { low }\end{array}$ & $\begin{array}{c}\text { Used for all } \\
\text { diseases }\end{array}$ \\
\hline 7. & Chetaki & $\begin{array}{l}\text { Fruit having } \\
\text { three ridges }\end{array}$ & $\begin{array}{l}\text { Fruit having three } \\
\text { ridges and weighs } \\
5-7 \mathrm{gm}\end{array}$ & $\begin{array}{l}\text { Used as } \\
\text { purgative }\end{array}$ \\
\hline
\end{tabular}


variety of TC was analyzed based on external features and organoleptic qualities are presented in Table 2 and Figure 1 to 5. Plant wise analysis showed that the Amrita variety has bigger leaf with 7-9cm length and 5-8 $\mathrm{cm}$ breadth compare to Rohini of 3-6 $\mathrm{cm}$ in length and 3-5 cm breadth with variations in color and shape and hairy nature. Flower color is varies from white and yellow in Abhaya, Pootana and Vijaya, Rohini and Amrita respectively. The biggest among the fruit is Amrita with 3.5-4.8X3.5$4 \mathrm{CM}$ dimension compare to Pootani $2-3 \mathrm{X} 1.5-2.5 \mathrm{~cm}$, the shape is varies from spherical to spindle and ridges were prominent in Abhaya, Vijaya, Rohini and Amrita as presented in Table 3. Physicochemical study of different fruits suggests there is no much difference was seen among the varieties (Table 4).

The microscopic study of fruits showed that the pericarp having epidermis with single layered made of cells having a swollen base and hair like prolongation with dimension of $168 \mu \mathrm{m}-91 \mu \mathrm{m}$ length and breadth of 14-7 $\mu \mathrm{m}$. The cortex is wide made up of parenchyma cells without intercellular spaces some of which contain rosette like crystals of calcium oxalate. It is intermingled with stone cells of diverse shapes. The stone cells found towards the periphery are tangentially elongated with narrow lumen. The diameter of the stone cells become lesser and the size of the lumen increases towards the inside. The central region is occupied by round or oval stone cells found in groups, having broad lumen. Most of the cells of the cortex contain simple or compound starch grains; the vascular bundles are conjoint, collateral and endarch. The powder examination indicates it is smooth, light yellow to brownish, astringent with characteristic odour. The fluorescence study has shown the different color in different variety of fruit as presented in Table 5. Preliminary phytochemical analysis of the aqueous and alcoholic extract revealed the presence of glycosides, flavonoids, tannins, phenols, saponins, diterpenes, carbohydrates and proteins etc. (Table 6).

The HPTLC study suggested that the alcoholic and water extract of different varieties showed the presence of Chebulinic acid and Gallic acid at the $\mathrm{Rf}$ value of $0.332+/-0.010$ and $0.782+/-0.010$ respectively Figure no. 6 -7. Rutin and Quercetine were not reported in our study since these are more soluble in Methanol rather in Alcohol. ${ }^{18,19}$ The percentage of Chebulinic acid was more in Abhaya water extract (3.82\%) than Vijaya

Table 2: Relative morphological study of Terminalia chebula Retz.

\begin{tabular}{|c|c|c|c|c|c|}
\hline SI. No & Variety & \multicolumn{2}{|c|}{ Ayurvedic textual Characters } & Flora of British India & Observation \\
\hline 1. & $\begin{array}{l}\text { Vijaya } \\
\text { Termenalia } \\
\text { chebula } \\
\text { Ver. } 2\end{array}$ & $\begin{array}{l}\text { Having Alabu } \\
\text { (Fruit of } \\
\text { Lagenaria } \\
\text { vulgaris Ser.) } \\
\text { shape }\end{array}$ & $\begin{array}{l}\text { Elongated shape } \\
\text { without ridges } \\
\text { and }<8 \mathrm{gm}\end{array}$ & $\begin{array}{l}\text { Leaves nearly glabrous beneath or the } \\
\text { interstices of the ultimate nerves with } \\
\text { minute sunk white tomentum with } \\
\text { young ovary quite glabrous with ovate } \\
\text { fruit and round based leaves }\end{array}$ & $\begin{array}{l}\text { Flask or Bottle shape with dark yellow colour with less } \\
\text { prominent ridges. Size: } 3.5 \text { to } 5 \mathrm{CM} \text { L, } 1.5 \text { to } 2.5 \mathrm{~cm} \text { Breadth } \\
\text { with } 4.8 \text { to } 5.6 \mathrm{gm} \text { weight per fruit. Mesocarp is light yellow } \\
\text { color with } 0.4 \text { to } 0.8 \mathrm{~cm} \text { thickness. Seed is stony hard with oval } \\
\text { shape and Cream color with size of } 1.7 \text { to } 2.3 \mathrm{~cm} \text { Length and } 1 \\
\text { to } 1.2 \mathrm{~cm} \text { Breadth. Centre of seed, Brown color two cotyledon } \\
\text { with radical and plemule seen. The endosperm is varies from } \\
0.3 \text { to } 0.4 \mathrm{~cm} \text { circumference }\end{array}$ \\
\hline 2. & $\begin{array}{c}\text { Rohini } \\
\text { Termenalia }\end{array}$ & Round in & $\begin{array}{l}\text { Circular, } \\
\text { without ridges }\end{array}$ & Adult leaves very shaggy beneath, fruit & $\begin{array}{c}\text { Spherical to Ovular shape and dark yellow colored with slender } \\
\text { hairs on its surface. Size is of } 2.5 \text { to } 2.4 \mathrm{~cm} \mathrm{~L}, 1.5 \text { to } 2 \mathrm{~cm} \text { Breadth } \\
\text { and } 3.01 \text { to } 3.31 \text { gm weight per fruit. Mesocarp is dark yellow } \\
\text { with } 0.2 \text { to } 0.3 \mathrm{~cm} \text { thickness }\end{array}$ \\
\hline 2. & $\begin{array}{c}\text { chebula } \\
\text { Ver. } 3\end{array}$ & shape & yellow color & mucn smaller oilen $/ 4$ inch witn small & $\begin{array}{l}\text { Seed: Big stony hard, cream colored Oval to spherical shape } \\
\text { with } 1.5 \text { to } 1.9 \mathrm{~cm} \text { Length and } 1.3 \text { to } 1.5 \mathrm{~cm} \text { Breadth. Endosperm } \\
\text { is white color varies from } 1 \text { to } 1.2 \mathrm{~cm} \mathrm{~L} \text { and } 0.4 \text { to } 0.5 \mathrm{~cm} \text { breadth } \\
\text { which is covered by brown inter cotyledon membrane. } \\
\text { Spherical to Ovular shape and dark yellow colored with with }\end{array}$ \\
\hline 3. & $\begin{array}{l}\text { Pootana } \\
\text { Termenalia } \\
\text { chebula } \\
\text { Ver. } \\
\text { Tomentella }\end{array}$ & $\begin{array}{l}\text { Size is small, } \\
\text { with stony } \\
\text { mesocarp } \\
\text { and big seed }\end{array}$ & $\begin{array}{l}\text { Very small size } \\
\text { with }<4 \mathrm{gm} \\
\text { weight with } \\
\text { stony mesocarp } \\
\text { and big seed }\end{array}$ & $\begin{array}{l}\text { Leaves when young densely coppery- } \\
\text { pubescent beneath, when adult } \\
\text { pubescent or glabrous. Fruits ovoid } \\
\text { hardly linch }\end{array}$ & $\begin{array}{c}\text { slender hairs on its surface. Size: } 2 \text { to } 3 \mathrm{CM} \mathrm{L} \text { and } 1.5 \text { to } 2.5 \mathrm{~cm} \\
\text { Breadth with } 4.5 \text { to } 5.3 \mathrm{gm} \text { weight per fruit. mesocarp is light } \\
\text { yellow hard with } 0.3 \text { to } 0.4 \mathrm{~cm} \text { thickness Seed is big Stony hard } \\
\text { with spherical shape and cream color with size of } 1.5 \text { to } 2.2 \mathrm{~cm} \\
\text { Length and } 1.3 \text { to } 1.5 \mathrm{~cm} \text { Breadth. Endosperm is white with } 0.5 \\
\text { to } 0.7 \mathrm{~cm} \mathrm{~L} \text { and } 0.3 \text { to } 0.5 \mathrm{~cm} \text { breadth. }\end{array}$ \\
\hline 4. & $\begin{array}{l}\text { Amirtha } \\
\text { Termenalia } \\
\text { chebula } \\
\text { Ver. } \\
\text { Gangitica }\end{array}$ & $\begin{array}{l}\text { Mesocarp } \\
\text { is more and } \\
\text { fleshy }\end{array}$ & $\begin{array}{l}\text { Mesocarp is } \\
\text { more and fleshy } \\
\text { with small seed } \\
\quad<7 \mathrm{gm}\end{array}$ & $\begin{array}{l}\text { Adult leaves with brown red silky hairs } \\
\text { on the both surfaces (some time extends } \\
\text { to stems also) }\end{array}$ & $\begin{array}{l}\text { Ovular to quadrangular in shape with dark yellow to brown in } \\
\text { colour. The hairs are prominent with reddish colored during } \\
\text { in young stage and have a } 3-4 \text { prominent ridges. Size: } 3.5 \text { to } \\
4.8 \mathrm{CM} \mathrm{L} \text { and } 3.5 \text { to } 4 \mathrm{~cm} \text { Breadth with } 7.3 \text { to } 8.5 \mathrm{gm} \text { weight per } \\
\text { fruit. The mesocarp is brown color with } 0.5 \text { to } 1.2 \mathrm{~cm} \text { thickness. } \\
\text { The seed is stony hard with Oval to spherical shape and light } \\
\text { reddish color with size of } 1.9 \text { to } 2.5 \mathrm{~cm} \text { Length and } 1.5 \text { to } 2.5 \mathrm{~cm} \\
\text { Breadth. Endosperm is white with } 1.3 \text { to } 2 \mathrm{~cm} \mathrm{~L} \mathrm{and} 0.5 \text { to } \\
0.7 \mathrm{~cm} \text { breadth. }\end{array}$ \\
\hline 5. & $\begin{array}{l}\text { Abhya } \\
\text { Termenalia } \\
\text { chebula } \\
\text { Ver. } \\
\text { Parviflora, } \\
\text { Thewaites } \\
\text { Enum. }\end{array}$ & $\begin{array}{l}\text { Fruit having } \\
\text { five ridges }\end{array}$ & $\begin{array}{l}\text { Fruit having } \\
\text { five ridges and } \\
\text { weighs } 7-9 \mathrm{gm}\end{array}$ & $\begin{array}{l}\text { Calyx teeth pubescent, flowers and fruits } \\
\text { are not smaller. Fruits more acutely } \\
\text { ribbed }\end{array}$ & $\begin{array}{l}\text { Spindle shape with wide in the middle then tapering ends } \\
\text { and Dark yellow colour with Glabrous/Shiny surface with } 5 \text { - } \\
\text { Prominent ridges. Size is of } 3 \text { to } 4 \mathrm{CM} \mathrm{L} \text { and } 2 \text { to } 2.5 \mathrm{~cm} \text { Breadth } \\
\text { with } 5 \text { to } 7.8 \mathrm{gm} \text { weight per fruit. The mesocarp is slight pinkish } \\
\text { to light yellow color with } 0.3 \text { to } 0.5 \mathrm{~cm} \text { thickness with } 5 \text { hallow } \\
\text { scattered across diagonal mesocarp. Seed is big Stony hard with } \\
\text { Oval shape and Cream color with size of } 1.5 \text { to } 2.5 \mathrm{~cm} \text { Length } \\
\text { and } 1 \text { to } 1.5 \mathrm{~cm} \text { Breadth. The endosperm is of white color with } \\
0.5 \text { to } 0.7 \mathrm{~cm} \mathrm{~L} \mathrm{and} 0.4 \text { to } 0.5 \mathrm{~cm} \text { breadth. }\end{array}$ \\
\hline
\end{tabular}




\begin{tabular}{|c|c|c|c|c|c|c|}
\hline SI. No & Character & Vijaya & Rohini & Pootana & Amirtha & Abhaya \\
\hline \multicolumn{7}{|l|}{ Leaves } \\
\hline 1 & Size & $\begin{array}{c}5-7 \mathrm{~cm} \mathrm{~L} \text { and } \\
4-6 \mathrm{~cm} \mathrm{~B}\end{array}$ & $3-6 \mathrm{~cm} \mathrm{~L}$ and $3-5 \mathrm{~cm} \mathrm{~B}$ & $\begin{array}{c}5-7 \mathrm{~cm} \mathrm{~L} \text { and } 4-6 \\
\mathrm{~cm} \mathrm{~B}\end{array}$ & $\begin{array}{c}7-9 \mathrm{~cm} \mathrm{~L} \text { and } 5-8 \\
\mathrm{~cm} \mathrm{~B}\end{array}$ & $5-7 \mathrm{~cm} \mathrm{~L}$ and $3-5 \mathrm{~cm} \mathrm{~B}$ \\
\hline 2 & color & Green & Green & $\begin{array}{l}\text { Young: Reddish Adult: } \\
\text { Green }\end{array}$ & Greenish & Yellowish green \\
\hline 3 & Shape & $\begin{array}{l}\text { Elliptic with } \\
\text { round base }\end{array}$ & Ovate with round base & $\begin{array}{c}\text { Lanceolate to ovate- } \\
\text { lanceolate }\end{array}$ & Ovate-lanceolate & $\begin{array}{c}\text { Lanceolate with round } \\
\text { base }\end{array}$ \\
\hline 4 & Hairy Nature & $\begin{array}{l}\text { Slightly } \\
\text { glabrous }\end{array}$ & $\begin{array}{c}\text { Slight hairs on both } \\
\text { surfaces }\end{array}$ & Adult: Pubescent & $\begin{array}{l}\text { Brown silky hairs on } \\
\text { both surfaces }\end{array}$ & Glabrous or shiny \\
\hline \multicolumn{7}{|l|}{ Flowers } \\
\hline 5 & Color & Yellowish & Yellowish & Whitish & $\begin{array}{c}\text { Yellowish with pink } \\
\text { stalk }\end{array}$ & Whitish \\
\hline 6 & Inflorescence & $\begin{array}{l}\text { Terminal spike } \\
\text { with panicles }\end{array}$ & $\begin{array}{c}\text { Terminal spike with } \\
\text { panicles }\end{array}$ & $\begin{array}{c}\text { Terminal spike with } \\
\text { panicles }\end{array}$ & $\begin{array}{c}\text { Terminal spike with } \\
\text { panicles }\end{array}$ & $\begin{array}{c}\text { Terminal spike with } \\
\text { panicles }\end{array}$ \\
\hline 7 & Size of flower & 0.5 to $0.7 \mathrm{CM}$ & 0.4 to $0.6 \mathrm{CM}$ & 0.5 to $0.7 \mathrm{CM}$ & 0.5 to $0.6 \mathrm{CM}$ & 0.5 to $0.6 \mathrm{CM}$ \\
\hline 8 & Ovary nature & $\begin{array}{c}\text { Ovary } \\
\text { glabrous }\end{array}$ & Ovary glabrous & Pubescent ovary & Ovary glabrous & $\begin{array}{l}\text { Pubescent calyx and } \\
\text { ovary }\end{array}$ \\
\hline \multicolumn{7}{|l|}{ Fruits } \\
\hline 1 & Size & $3.5-5 \times 1.5-2.5$ & $2.5-2.4 \times 1.5-2$ & $2-3 \mathrm{X} 1.5-2.5$ & $3.5-4.8 \times 3.5-4$ & $3-4 \mathrm{X} 2-2.5$ \\
\hline 2 & Shape & Bottle or flask & Round & $\begin{array}{l}\text { Spherical to } \\
\text { ovular }\end{array}$ & $\begin{array}{l}\text { Ovular to } \\
\text { quadrangular }\end{array}$ & Spindle shape \\
\hline 3 & Color & Dark Yellow & Dark Yellow & Dark Yellow & $\begin{array}{l}\text { Dark Yellow to } \\
\text { brown }\end{array}$ & Light Yellow \\
\hline 4 & Weight per fruit & 4.8-5.6GM & 3-3.3GM & 4.5-5.3GM & 7.3-8.5GM & $5-7.8 \mathrm{GM}$ \\
\hline 5 & Hairy nature & Nil & Slight hairs & Slight hairs & $\begin{array}{l}\text { Reddish hairs when } \\
\text { it is young }\end{array}$ & Glabrous/Shiny \\
\hline 6 & Ridge & $\begin{array}{l}\text { Ridges not } \\
\text { prominent }\end{array}$ & No ridges & No ridges & 3-4 prominent ridges & 5- Prominent ridges \\
\hline
\end{tabular}

Table 4: Physicochemical study.

\begin{tabular}{cccccc}
\hline Variety & Vijaya & Rohini & Pootana & Amirtha & Abhaya \\
\hline $\begin{array}{c}\text { Ash value } \\
\text { Acid in insoluble }\end{array}$ & $3.2 \%$ & $3.4 \%$ & $3.7 \%$ & $4.1 \%$ & $4.2 \%$ \\
$\begin{array}{c}\text { ash } \\
\text { Water soluble ash }\end{array}$ & $0.3 \%$ & $0.3 \%$ & $0.4 \%$ & $0.4 \%$ & $0.5 \%$ \\
extractive value & $43 \%$ & $5 \%$ & $5 \%$ & $6 \%$ & $7 \%$ \\
$\quad \begin{array}{c}\text { water } \\
\text { Alcoholic }\end{array}$ & $46 \%$ & $49 \%$ & $48 \%$ & $35 \%$ & $42.5 \%$ \\
extractive value & & $57 \%$ & $56 \%$ & $54.5 \%$ \\
$\begin{array}{c}\text { Moisture content } \\
\text { Foreign matter }\end{array}$ & $8 \%$ & $9 \%$ & $8.3 \%$ & $8.7 \%$ & $9 \%$ \\
Crude fiber & $28 \%$ & $15 \%$ & $21.5 \%$ & $25 \%$ & $23.5 \%$ \\
\hline
\end{tabular}

water extract (2.09\%) and Vijaya alcoholic (3.07\%) than Abhaya Alcoholic (2.2\%) and Gallic acid was more in Rohini water extract (3.12\%) than Pootani water (1.12\%) it was least in alcoholic extract as presented in Figure 8-9.

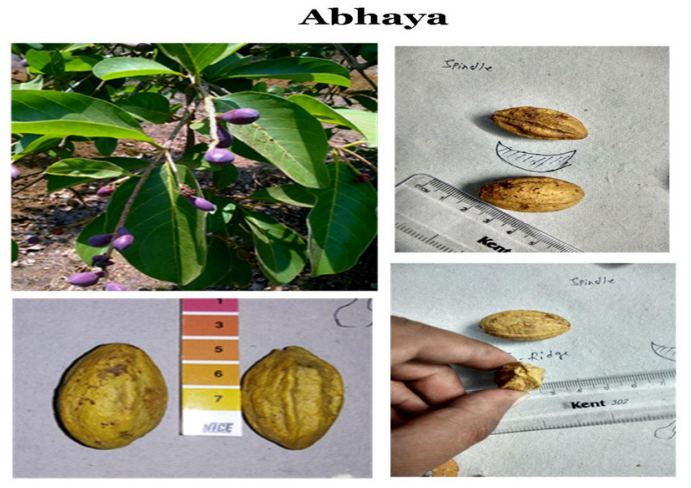

Figure 1: Abhaya variety of Myrobalan physical study.

\section{DISCUSSION}

The current study is first of its kind in identification and possible co-relation of available sources of TC thus it as identified only 5-varieties as the study was restricted in north-western ghats of north Karnataka more- 
Table 5: Fluorescence and behavior of powdered fruits under UV light and white light on treat-

\begin{tabular}{|c|c|c|c|c|c|c|c|c|c|c|}
\hline \multirow{2}{*}{ Reagent } & \multicolumn{2}{|c|}{ Vijaya } & \multicolumn{2}{|c|}{ Rohini } & \multicolumn{2}{|c|}{ Pootana } & \multicolumn{2}{|c|}{ Amirtha } & \multicolumn{2}{|c|}{ Abhaya } \\
\hline & $\mathrm{WL}^{\#}$ & $F^{\#}$ & WL & $F$ & WL & $\mathrm{F}$ & WL & $\mathbf{F}$ & WL & $\mathbf{F}$ \\
\hline Plane powder & $\begin{array}{l}\text { Light } \\
\text { yellow }\end{array}$ & + & $\begin{array}{l}\text { Light } \\
\text { yellow }\end{array}$ & + & Yellow & + & Brownish & + & $\begin{array}{l}\text { Light } \\
\text { brown }\end{array}$ & + \\
\hline Water & Yellowish & - & $\begin{array}{l}\text { Light } \\
\text { brown }\end{array}$ & - & $\begin{array}{l}\text { light } \\
\text { yellow }\end{array}$ & - & $\begin{array}{c}\text { Deep } \\
\text { brown }\end{array}$ & - & Brown & - \\
\hline Aq Iodine & $\begin{array}{l}\text { Light } \\
\text { brown }\end{array}$ & - & Dark & - & $\begin{array}{l}\text { Deep } \\
\text { brown }\end{array}$ & - & Brown & - & $\begin{array}{l}\text { Light } \\
\text { dark }\end{array}$ & - \\
\hline Nitric acid & Orange & + & Orange & + & Orange & + & Orange & + & $\begin{array}{l}\text { light } \\
\text { orange }\end{array}$ & + \\
\hline Picric acid & $\begin{array}{c}\text { Dark } \\
\text { yellow }\end{array}$ & + & Yellow & + & $\begin{array}{l}\text { Light } \\
\text { yellow }\end{array}$ & + & Yellow & + & $\begin{array}{l}\text { Light } \\
\text { yellow }\end{array}$ & + \\
\hline $20 \% \mathrm{NaOH}$ & $\begin{array}{c}\text { Dark } \\
\text { Brown }\end{array}$ & - & $\begin{array}{c}\text { Dark } \\
\text { Brown }\end{array}$ & - & $\begin{array}{c}\text { Dark } \\
\text { Brown }\end{array}$ & - & $\begin{array}{c}\text { Dark } \\
\text { Brown }\end{array}$ & - & $\begin{array}{c}\text { Light } \\
\text { red }\end{array}$ & - \\
\hline
\end{tabular}

\# WL: White light and F: Fluorescence

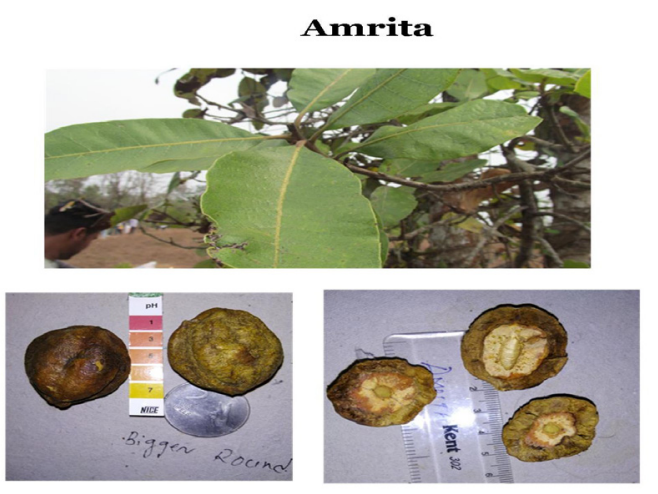

Figure 2: Amrita variety of Myrobalan physical study.

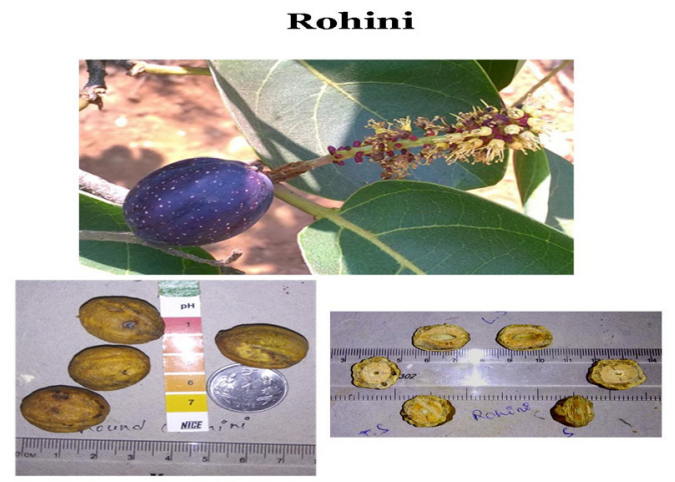

Figure 4: Rohini variety of Myrobalan physical study.

over, Ayurvedic literature suggested that few varieties of TC are known to available only in sub Himalayan region. ${ }^{2}$ Distribution of TC plants in different altitude depicts that Amrita variety with 2716 foot alt has less \% of phytochemicals compare to Rohini with 2656 foot, it potentiated the similar study conducted in different altitude of same plant with variability in phytochemicals suggested the higher altitude plants are rich source

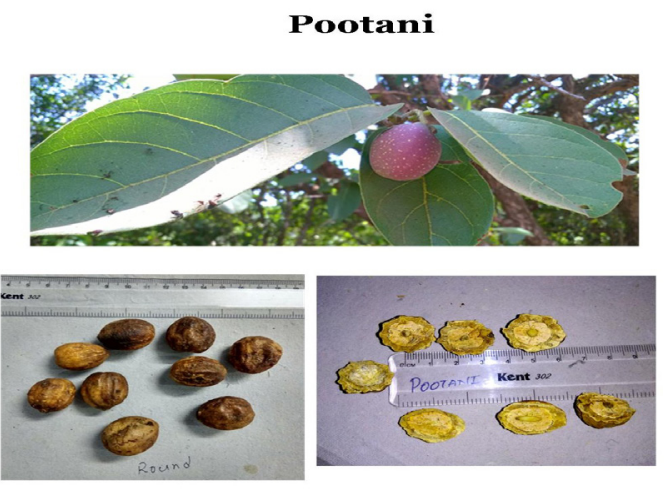

Figure 3: Pootani variety of Myrobalan physical study.

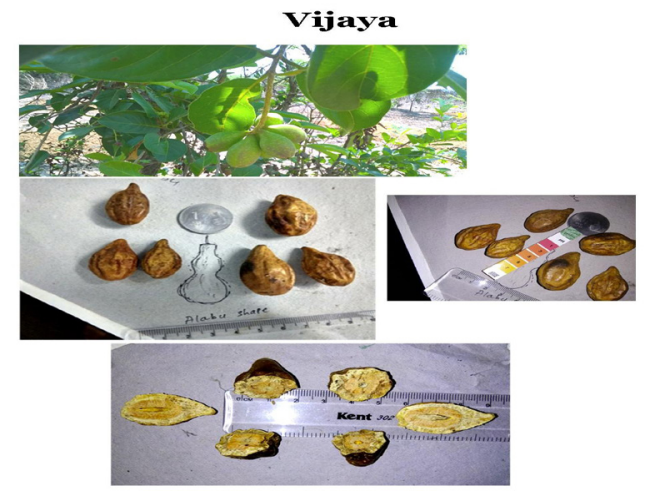

Figure 5: Vijaya variety of Myrobalan physical study.

of phytochemicals than in lower altitude. ${ }^{20}$ This could be the rationality of selecting higher altitude plants for clinical purpose in Ayurveda.

HPTLC study showed the presence of Chebulinic acid and Gallic acid and absence in quercetine and rutin as these chemicals are more soluble in Methanol than in other solvent. ${ }^{21}$ The percentage of phytochemicals were more in water soluble extract compare to alcoholic extract, this could be the reason that TC formulations are more of water based. 


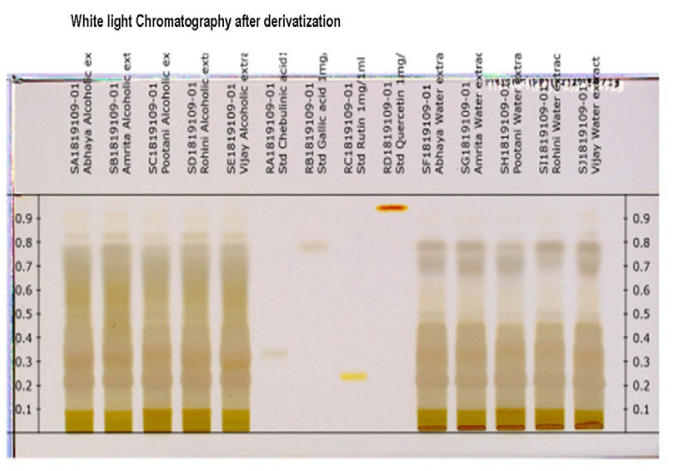

Figure 6: HPTLC Chromatography white light after derivatization.

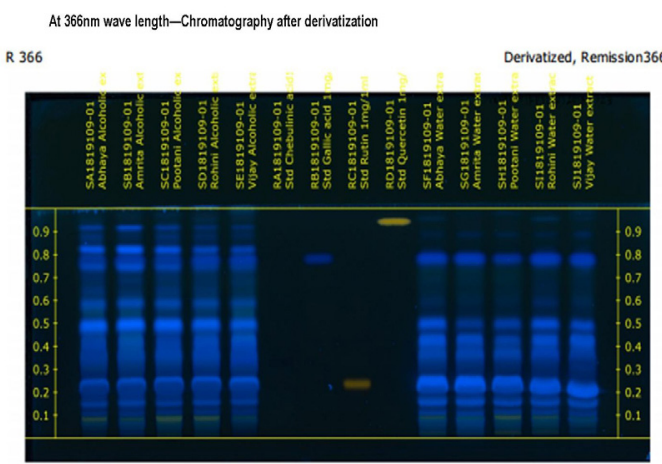

Figure 7: HPTLC Chromatography at $366 \mathrm{~nm}$ wave length.

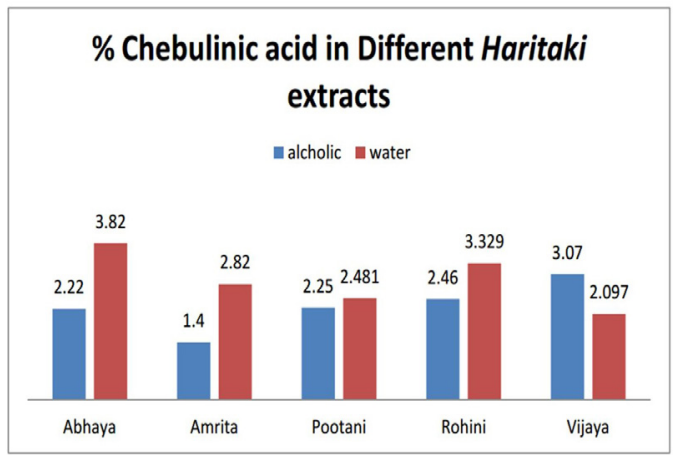

Figure 8: $\%$ of Chebulinic acid in different Myrobalan.

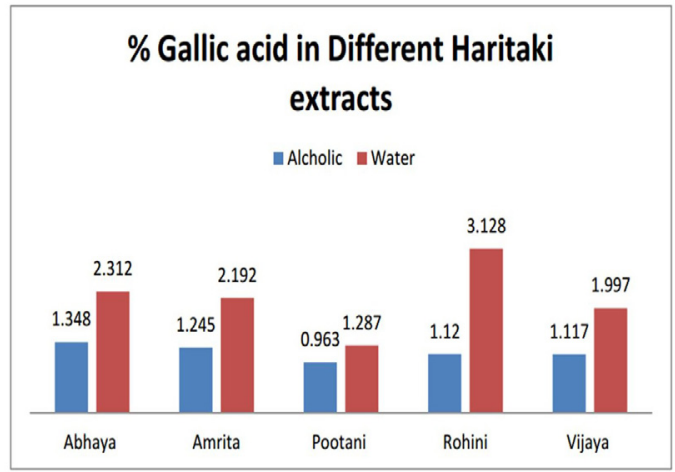

Figure 9: $\%$ of Gallic acid in different Myrobalan.

Table 6: Preliminary phytochemical analysis.

\begin{tabular}{|c|c|c|c|c|c|}
\hline \multirow{2}{*}{ Test } & \multicolumn{5}{|c|}{ Alcohol/Water Extract Samples } \\
\hline & Vijaya & Rohini & Pootana & Amirtha & Abhaya \\
\hline Carbohydrates & $+/+$ & $+/+$ & $+/+$ & $+/+$ & $+/+$ \\
\hline Pentose Sugars & $+/+$ & $+/+$ & $+/+$ & $+/+$ & $+/+$ \\
\hline Starch & $+/+$ & $+1+$ & $+/+$ & $+/+$ & $+/+$ \\
\hline Proteins & $+/+$ & $+/+$ & $+/+$ & +/+ & $+/+$ \\
\hline Alkaloid & $+/+$ & $+/+$ & $+/+$ & $+/+$ & $+/+$ \\
\hline Steroids & $-1-$ & $-1-$ & $-1-$ & $-1-$ & $-1-$ \\
\hline $\begin{array}{l}\text { Saponins: } \\
\text { Foam test }\end{array}$ & -/ Slightly present & -/ Slightly present & -/ Slightly present & -/ Slightly present & -/ Slightly present \\
\hline Anthraquinon glycoside & $+/+$ & $+/+$ & $+/+$ & $+/+$ & $+/+$ \\
\hline Tannins and Phenolic compounds & $+/+$ & $+/+$ & $+/+$ & $+/+$ & $+/+$ \\
\hline Iron & + & + & + & + & + \\
\hline Calcium & + & + & + & + & + \\
\hline Magnesium & + & + & + & + & + \\
\hline Sodium & + & + & + & + & + \\
\hline Potassium & - & - & - & - & - \\
\hline Sulphate & - & - & - & - & - \\
\hline Phosphate & + & + & + & + & + \\
\hline Chloride & + & + & + & + & + \\
\hline Carbonate & + & + & + & + & + \\
\hline
\end{tabular}


Vijaya variety of TC has contained more percentage of Chebulinc acid and it is known for its potential action on GI tract as anti-tumour ${ }^{21}$ antiangiogenic, ${ }^{22}$ anti-inflammatory ${ }^{23}$ and anti-hypertensive ${ }^{24}$ effects thus Ayurveda suggested to use these for curative purpose. ${ }^{2}$ Rohini and $A b$ haya variety of TC are with maximum percentage of Gallic acid (Hydrolisable poly-phenol), this gallic acid is active ingredient known for its activities on free radical-scavenging, elastase inhibition, expression of matrix metalloproteinase-1 (MMP-1) and type I collagen synthesis in normal human fibroblast cells. ${ }^{25-26}$ Thus, these actions may be useful in the management of Vrina (ulcer), geriatric population and GI disorder suggested by Ayurveda. ${ }^{22}$

\section{Study Limitations and Scope}

The current study merely provided the existence of difference varieties of TC and these varieties have shown actual variations in there phytochemicals. This variation could be because of distribution of plants, age of plant, genetical and time of collection etc. thus, actual gene variations and molecular identification of these plants can be assessed by RAPD (Random Amplified Polymorphic DNA) study. Thus, confirmed varieties can further verified on its clinical efficacy. This study has made initial efforts on identifying source plants for types of Haritaki, Further studies collecting samples from all over India might be helpful in better understanding.

\section{CONCLUSION}

The study potentially demonstrated the availability of varieties of Myrobalan explained according to Ayurveda. Among the 7 varieties, 5-different varieties are identified in North-western Ghats of north karnataka as Vijaya, Rohini, Pootana, Amirtha and Abhaya these can be correlated to Termenalia chebula Ver. 2 (typica/citrina), TC Ver. 3, TC Ver. Tomentella, TC Ver. Gangitica and TC Ver. Parviflora, Thewaites Enum respectively. There was gross phyto-chemical variation existed among these and this would certainly open the new research question on its genetical identity and efficacy.

\section{ACKNOWLEDGEMENT}

Authors acknowledge to Rajiv Gandhi University of Health sciences Bangalore for financial support in conduction of this study and VGST Govt. Karnataka for upgrading research lab and smooth conduction of this research at Rajiv Gandhi Education Society's Ayurvedic Medical College Hospital and PG Research Centre Ron, Gadag. Karnataka.

\section{CONFLICT OF INTEREST}

The authors declare no conflict of interest.

\section{ABBREVIATIONS}

TC: Termenalia chebula; L: Length; B: Breadth; WL: White light; F: Fluorescence; +: Present and -: Absent.

\section{REFERENCES}

1. Kirtikar KR, Basu BD. Indian Medicinal Plants. LM Basu Allahabad. 1935;1:1020-
2. Chunekar KC, Bhavaprakashnighant. Varanasi: Chaukhamba Bharati Academy. 1999;4-5.

3. Hooker JD. Flora of British India. London: L Reeve. 1854;2:443-9.

4. Brandis D. India Trees. Dehradun, India: Bishen Singh Mahendra Pal Singh. 1987;308.

5. Lemmens RHMJ, Soerianegara I, Wong WC. Plant Resources of South-East Asia. Timber tree: Minor commercial timber. Indonesia: Prosea Publishers. 1995;475-8.

6. Lemmens RHMJ, Wulijarni-Soetjipto N. Plant Resources of South-East Asia. No. 3: Dye and tannin-producing plants: Prosea Foundation. Indonesia. 1992;122-5.

7. Gupta PC. Biological and Pharmacological Properties of Terminalia chebula Retz. Haritaki)- An Overview. Int J Pharm Pharm Sci. 2012;4(3):62-8.

8. Kumar A, Lakshman K, Jayaveera K, Satish K, Tripathi SM. Estimation of rutin and quercetin Terminalia chebula by HPLC. Int J Aesth Antiag Med. 2009;2(1):3.

9. Jayaramkumar K. Effect of geographical variation on content of tannic acid, gallic acid, chebulinic acid and ethyl gallate in Terminalia chebula fruits. Nat Prod. 2006;2(3-4):170-5

10. Juang LJ, Sheu SJ, Lin TC. Determination of hydrolyzable tannins in the fruit of Terminalia chebula by High-performancc Liquid Chromatography and capillary electrophoresis. J Sep Sci. 2004;27(9):718-24.

11. Williumson EN. Major herbs of Ayurveda. London: Churchill Livingstone. 2002;299.

12. Tubtimdee C, Shotipruk A. Extraction of phenolics from Terminalia chebula Retz. with water-ethanol and water-propylene glycol and sugaring-out concentration of extracts. Sep Puri Tech. 2011;77(3):339-46.

13. Thakur M, Rana RC, Thakur S. Physiochemical evaluation of Terminalia chebula fruits. J Non-Timber Forest Prod. 2008;15:37-42.

14. Zhang $X$, Chen $\mathrm{C}, \mathrm{He} \mathrm{S}$, Ge F. Supercritical- $\mathrm{CO}_{2}$ fluid extraction of the fatty oil in Terminalia chebula and GC-MS analysis. Zhong Yao Cai. 1997;20(9):463-4.

15. Mammen D, Bapat S, Sane R. An investigation to variation in constituents in the fruits of Terminalia chebula Retz. At different maturity stages. Int J Pharm Bio Sci. 2012;3(1):416-9

16. Gupta AK, Tandon N, Sharma M. Quality standards of Indian medicinal plant. New Delhi: Indian Council of Medical Research. 2003;207-9.

17. Kumar A, Lakshman K, Jayaveera KN, Mani TSN, Satish KV. Estimation of Gallic Acid, Rutin and Quercetin in Terminalia chebula by HPTLC. JJPS. 2010;3(1):63-7.

18. Krishna KVVS, Gouri SK, Syam VM, Tamizhmani T. Simultaneous Estimation of Chebulagic acid and Chebulinic acid in Marketed Polyherbal Formulations by HPTLC. Int J Pharm Tech Res. 2013;5(4):1554-60.

19. Rajasekaran A, Arivukkarasu R, Archana D. HPTLC Method for estimation of Gallic acid and Rutin in Haritaki -An Ayurvedic Formulation. Int J Pharm Tech Res. 2011;3(2):986-99.

20. Sharma R, Naik $S$, Saroch $V$, Chasoo G. A comparative anticancer activity of Plumbago Zeylanica collected from northern and southern parts of India. JWorld Journal of Pharmaceutical Research. 2015;4(7):1145-51.

21. Yi ZC, et al. Effects of chebulinic acid on differentiation of human leukemia K562 cells. Acta Pharmacol Sin. 2004;25(2):231-8.

22. Lu K. et al. Triphala and its active constituent chebulinic acid are natural inhibitors of vascular endothelial growth factor-a mediated angiogenesis. PLoS One. 2012;7(8):e43934

23. Yang MH, Ali Z, Khan IA, Khan SI. Anti-inflammatory activity of constituents isolated from Terminalia chebula. Nat Prod Commun. 2014;9(7):965-8.

24. Guan YY, Kwan CY, Hsu FL, Cheng JT. In vitro inhibitory effects of chebulinic acid on the contractile responses of cardiovascular muscles. Clin Exp Pharmacol Physiol. 1996;23(8): 747-50.

25. K. W. Lee, Y. J. Kim, D.-O. Kim, H. J. Lee, and C. Y. Lee, Major phenolics in apple and their contribution to the total antioxidant capacity. J Agr Food Chem. 2003;51(22):6516-20.

26. Mondal SC, Singh P, Kumar B, Singh SK, Gupta SK, Verma A. Ageing and potential anti-aging phytochemicals: An overview. World J Pharm Pharmaceutical Sci. 2014;4(1):426-54

Article History: Submission Date : 13-11-2018; Revised Date : 05-01-2019; Acceptance Date : 29-03-2019

Cite this article: Manjunath A, Kotturshetty IB, Vinod U. Identification and Validation of Different Types of Fruit of Haritaki (Terminalia chebula Retz.) in NorthWestern Ghats of North Karnataka with Special Reference to HPTLC. J Young Pharm. 2019;11(3):254-60. 